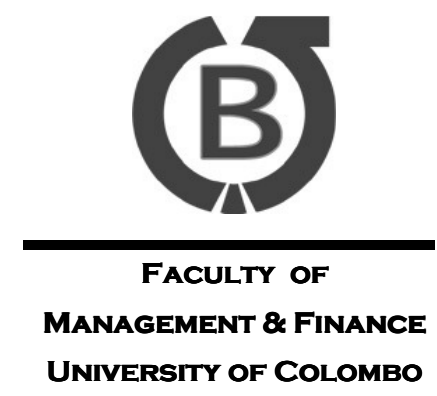

MANAGEMENT \& FINANCE
UNIVERSITY OF COLOMBO
Vol. 07, No. 02, December, 2016
Colombo

Business

Journal

International Journal

of Theory \& Practice

\title{
Challenges in Cruise Tourism in Relation to Shore Excursions: The Case of Sri Lanka
}

\author{
W. H. M. S. Samarathunga ${ }^{1}$ \\ Department of Tourism \& Hospitality Management, Rajarata University of Sri Lanka
}

\begin{abstract}
Although cruise tourism is one of the fastest growing segments of the international leisure tourism market, tourism research on ocean cruises have often been neglected in Sri Lanka. Cruise calls involve frequent shore excursions to attractions including both cultural and natural, in different parts of Sri Lanka. Thus, the aim of this study is to identify the challenges in cruise tourism in relation to shore excursions. The study is qualitative driven thus semi-structured interviews, discussions and participatory observation have been used as key research tools. Descriptive approaches were employed to analyze the data gathered. The findings emphasized that the shore excursion challenges are economic, natural and socio-cultural related, demand and supply related, and service providers related. The implications of the study can facilitate future researches, empirical studies, and strategy development relevant to cruise tourism.
\end{abstract}

Keywords: Cruise Call, Cruise Tourism, Leisure Tourism, Shore Excursions, Tourism

\section{Introduction}

With the decisive conclusion of the war in 2009, Sri Lanka with its peaceful environment is now considered as one of the safest destinations for tourists to travel (Godahewa, 2012). The critical factors to facilitate Cruise Lines to stop over in Sri Lankan Ports are developing, and only needs some development in the area of its service delivery to generate economic benefits of significance. The recent United Nations World Tourism Organization (UNWTO) report on Cruise Tourism (2011) shows a shift towards cruise travel, with consistent growth. The construction of new mega cruise ships and steady increase in their berth capacity also provide testimony of this trend, since demand is driven by supply of berth capacity. Luxury Cruise Travellers are relatively high-end spenders, and opinion leaders (International Luxury Travel Market, 2011). Therefore, the need is to provide them with accessibility to attractions, interests and shopping opportunities to enable them to spend. The country needs to attract these travellers to experience Sri Lanka as they would be the main drivers to improve 
tourism receipts of the country in near future. With cruise lines already navigating the seas off the coast of Sri Lanka, which is strategically located close to the East - West maritime highway, the deviation to call at Sri Lankan seaports is insignificant.

While food, accommodation and some entertainment are included in the ticket price, cruise passengers also spend money in the destinations they visit, primarily on taking excursions and shopping. Based on research in Queensland, passenger expenditure in Queensland destinations can be estimated to be about $\$ 110$ - $\$ 140$ per passenger. Crew members can also make a significant financial contribution to a destination as they take advantage of their off duty time to go ashore (Tourism Queensland, 2006). Cruise activities are an income generator for the industries that are directly involved in the provision of such services. It is also an income generator for destinations, as shore excursions and daily staying of cruise passengers are associated with tourism related spending (Pallis, 2015).

Shore excursions are optional tours of a destination offered for sale on board a cruise ship (Tourism Queensland, 2006). In many cases, cruises also offer excursions and other services as part of the overall package to make the product even more appealing (Dowling, 2006). Ray and Williams (2003) defined a shore excursion as an organized tour purchased by a cruise passenger in a port destination. Shore excursions may be land, water or air-based. Examples include activities such as kayaking, wildlife viewing, or cultural interpretation. Ray and Williams (2003) also, defined shore excursions as optional, guided tours in a cruise ship's port of call. They are offered in almost all cruise ports and cities and are a great way to enhance the cruise experience by allowing the tourists to see more of the places they visit. Shore excursions highlight the best local attractions and sight-seeing opportunities, the best places to shop, and give the cruise passenger a chance to experience the local culture.

Sri Lanka is blessed with many resources that perform as contributory factors for cruise tourism development in the country. Easy accessibility from main marine routes is the key contributory factor for cruise tourism development in Sri Lanka. According to Dole, the Chairman of the Cruise Tourism subcommittee of SLAITO Sri Lanka is located just 08 kilometres from the main shipping route that connects East and West. The deviation to Galle Harbour is just 30 minutes and 03 hours to Colombo harbour. Sri Lanka is blessed with both natural and cultural attractions and is famous for availability of distinct types of attractions among both Western and Eastern travellers. Its eight World Heritage sites, availability of the eighth wonder of the world Sigiriya, and the elephant captivity in Pinnawala are some of the key attractions in Sri Lanka (Berkmoes, Butler, \& Stewart, 2014). The cruise passengers sailing to Sri Lanka are thus interested in experiencing this diversity in a shorter period of time. Cruise directors check out possible new shore excursions and monitor existing ones (Dickinson and Vladimir, 1996). Availability of ample number of attractions can also be considered as a contributory factor. International Luxury Travel Market states (2011) that there is an increase in demand for open-range excursions. In such a situation the cruises are blessed with the attractions located at a closer proximity to Sri Lankan ports.

There are little over a dozen of cruise operators in Sri Lanka, conducting shore excursions on behalf of their principle operators, the cruises. Most operators maintain high standards in service operations considering the nature of this business, whilst the mediation of stand-alone companies, taxi services, and guides are also visible in the play. When an average tourist spends US \$ 160 per day in Sri Lanka (Sri Lanka Tourism Development Authority, 2015), per day expenditure of a cruise tourist, 
who spend average US $\$ 3000$ - 4000 per tour, is uncalculated (Tercek, 2015). Therefore, Sri Lanka is yet to grab the opportunity of this US \$ 04 billion worth industry (Athukorala, 2015).Many small island countries depend heavily on these excursionists for the foundations of their tourism industries, although there has been some debate in recent years about the real effects of cruise-based tourism (Dowling, 2006). Sri Lanka has identified tourism as a main driving force in the present development process (Ministry of Economic Development, 2011).

Shore excursions could be one of the main income sources in Sri Lanka that needs careful planning and implementation. Due to the significant amount of capital invested on ships, terminals, other infrastructure, and large number of passengers a ship carries, the cruise industry deserves particular attention in terms of research and economic analysis (Luković, 2012). However, in Sri Lanka, as elsewhere, the dominant theme in the literature has, invariably, been the emphasis on the argument that the tourism industry is a conduit of development of the developing countries to participate in the global economy. While this is not in dispute, the literature is silent on challenges in cruise tourism in relation to shore excursions. Accordingly, this exploratory study arises from identifying the knowledge gap related to the challenges faced by shore excursion service providers in Sri Lanka.

The subsequent sections of the paper provide an outline of the present state of relevant knowledge relevant to the definitions of cruise tourism industry and shore excursion, importance of the cruise tourism industry, challenges faced by cruise tourism operators in Sri Lanka, describe the research methodology employed, present findings and discussion, and finally the conclusions and, recommendations are proposed.

\section{Literature Review}

Preliminary review of literature enabled to group the challenges in relation to shore excursions in to three main groups. The first is challenges over economic, natural and socio-cultural environment. The second is demand related, and supply related that includes: satisfaction of the cruise tourist, infrastructure related, policy, safety and security. Finally, the service provider related challenges are listed.

\subsection{Economic, Natural and Socio-Cultural Challenges}

Luxury cruises carry high end clientele. This clientele, who are not price conscious are extremely sensitive to the quality of the services being provided. On-board revenue is derived from onshore activities, particularly from shore excursions and port shopping programs. Shore excursions are landbased tours sold by the cruise ship. However, the excursion service providers are not enjoying a significant profit margin since the ship absorbs most of it. Many researches have been carried out by scholars regarding the financial contribution of the shore excursions. According to Klein (2002), out of 50 to 80 percent of those who buy an excursion in each port, and provide solid revenue to the cruise line - as little as one-half to one-third of the shore excursion price is paid to the person providing the shore excursion. For example, a shore excursion costing a passenger US\$60 may yield the in-port provider US\$20 or less. Dowling (2006) agrees with Klein's (2002) findings. According to him, the shore excursion providers are in an uncomfortable position of being paid US $\$ 20$ for a product that passengers expect US $\$ 60$ of value. If passengers are disappointed, they blame the service provider; not the cruise ship. Klein (2005) again reinstated her opinion on the financial difficulties faced by the shore excursion operators through a case study conducted in St. Vincent and the Grenadines ports. 
According to him, a passenger spending US $\$ 50$ for a shore excursion expects a $\$ 50$ product, but the shore excursion provider only receives US $\$ 25$. While the cruise ship walks away with its cut, the shore excursion provider must provide a quality product that pleases passengers and the cruise line, while still retaining a small profit. If passengers are unhappy they will blame the shore excursion provider, unaware of the cruise line's cut, which can exceed 50 percent; one cruise line retains 90 percent of the cost of a shore excursion. Klein's study in 2006 on 'Turning Water in to Money' further states, the price of a shore excursion purchased on board is typically marked up between 70 to 200 percent, with less than half that amount paid to excursion operator. Brida and Zapata (2009) further strengthen this idea. According to them, from the value paid by cruisers for on shore activities, the local tour operator receives between 50 percent and sometimes 25 percent of that value. There are no profits for the chain of local tourism while cruise lines obtain all incomes, from rental of aquatic equipment, food and beverages, to souvenirs that are sold to passengers on board.

Sri Lanka is an island country with a relative low population. The impacts and challenges of shore excursions in an island country are also researched and documented. It is a fact in tourism literature that tourism is a social phenomenon that includes travelling of people to different societies to earn new experience, thus lifestyles and local traditions of island communities have become a tourism product. However, visitation to a port, destination, or to a country always leads to chaos. Ajagunna and Pinnock (2013) stated Nilsson's work (2007) who suggested that when big ships arrive at small ports, the congestion which arises will have an impact, not only on nature but also on the traditions and social behaviour of the local residents. Thus, cruising has the potential to affect even the most peripheral destinations, resulting in many "paradises lost" through development. United Nations Environment Programme (2005) through their detailed report on Issues and Challenges in Caribbean Cruise Ship Tourism disclosed that increased size of the cruise ship can cause overcrowding of port facilities, the urban setting and attractions; the second component of congestion is the perception of overcrowding by residents, tourists and cruise ship visitors. Residents and tourists may avoid visiting certain attractions and facilities because of the anticipated overcrowding by throngs of cruise ship visitors. This causes for the fall in demand to shore excursions.

Rapid inflows of cruise passengers may also cause short-term shortages in local transportation services, such as taxis and tour buses (Brida, Del Chiappa, Meleddu, \& Pulina, 2012). As the inflated demand is temporary, it may not be feasible to ameliorate shortages through increased capacity. Nova Scotia (a Canadian village of 120 inhabitants) experiences scarcity of a public service such as transport. In a day with a high presence of cruise passengers, the village provides 50 buses that bring congestion and pollution, and compete with pedestrian on the villager's roads (Klein, 2005). In fact, local residents avoid the central business district while cruise ships are in port (Loper, 2005). This situation differs from ports such as Miami, Barcelona and other European destinations, where the number of cruise visitors is small compared with tourists or the number of residents. Quality of life is directly impacted by the volume of visitors. As cited by Klein (2011) the United Nations Committee on Sustainable Tourism notes that cost of living as well as overcrowding, traffic congestion, and noise pollution increases when the social carrying capacity of an island is surpassed. It has been observed that a highly concentrated tourism generates more negative perceptions from residents towards tourist. Crowds disrupt usual routing and activities associated with cruise tourism can themselves be a problem (Klein, 2005). This situation is not only for residents but also for stay over tourists who have to spend lot of time in the row to visit a monument or museum, not finding space in the discotheque. And at the end, they feel themselves confused with the horde (Brida \& Zapata, 2009). Therefore it is 
vital to promote the shore excursions in a responsible manner without causing damages to the social value systems, social structures and protecting the regular tourists.

Cruise calls are extremely sensitive to the weather changes. When it comes to the shore excursions, the service providers are having just $4-8$ hours to complete an excursion and take the passengers back to the ships. Thus, there should not be any waiting time at the destinations. Unlike Sri Lanka, the cruise ship ports in the Caribbean are subject to tropical storms and hurricanes. In general cruise ship companies withdraw their services whenever there is a severe weather warning and resume service after the event has passed (United Nations Environment Programme [UNEP], 2005). But, by that time, the excursion service providers have allotted destinations, reservations are made, and buses are booked. This disruption is likely to have repercussions in Sri Lanka as well.

Apart from technical reasons, the cruises anchor at a harbour to engage in shore excursions. Thus, the port sea areas are becoming extremely busy with a high volume of ships. Cruise tourism, especially since the introduction of mega-ships, has come under heightened scrutiny due to the significant pressures this sector imposes upon vulnerable marine ecosystems. Johnson (2002) highlights some of the most pressing concerns, including: infrastructure impacts (e.g., degradation of coastal/marine habitats due to the construction of terminal facilities, use of local natural resources for construction, dredging and dumping of spoil); operational impacts (e.g., consumption of local resources by ships, water and air pollution, and damage caused to marine ecosystems by ships); distribution impacts (e.g., associated with passenger travel and industrial supply chain logistics); use impacts (e.g., cultural impacts on the local community, as well as disturbances to wildlife and natural environments); and waste impacts (e.g., from garbage, oils, sewage and other hazardous waste generated by ships). The difficulty in appraising such costs, Johnson argues, is framing them according to the same terms of reference used to present the economic benefits of cruise tourism. Johnson (2002) further exposed the environmental cruise tourism impacts identified by a study of British Airways in Seychelles: first, modifications to the natural and built environment to enable destinations to serve as a cruise line destination involve loss of natural habitat, exploitation of local construction. Second, Operational impacts related to the use of energy, water and those such as antifouling and accidental or deliberate physical damage to marine ecosystems. Third, impacts associated with transferring people to and from departure and destination points; it increases the use of air travel. Fourth, the impacts of recreational activities on wildlife such as disturbance and littering, and pressures on endangered species though exploitation for gifts and curios. Brida and Zapata (2009) also agree with above scholars on the environmental impacts of cruise tourism and shore excursions.

\subsection{Demand and Supply Related Challenges}

Whilst paying attention towards the economic, environmental and socio-cultural challenges, the operators need to pay attention on the factors that are more personal to the cruise passengers during an off-shore excursion. Dwyer and Forsyth (1996) identified what the cruise tourists did not like during their study: begging children, aggressive sales people and street selling (together making up 32 percent of dissatisfaction), followed by recreational activities (15 percent) or lack thereof. Power (2013) through his Cruise Line Satisfaction Report identifies the key factors in customer satisfaction in cruise ships as: service, stateroom, food, embark/debark, entertainment, cost, excursions. Thus, it is essential to pay more attention on these factors to make the shore excursions more successful.

One of the main challenges of shore excursions is the absence of knowledge on the possible demand for shore excursions till the last moment. This situation pressurizes the operators to maintain 
either excess or insufficient facilities for the excursionists. McKenzie Wilson Network Partnership Group (2004) also identified this situation. According to them, passengers buy their excursions two days or even one day before arrival in port. An attraction will therefore not know if they are going to receive 30 or 300 passengers until the day before or even on the morning arrival. A coach company will not know whether one or six coaches are required. Klein (2006), whilst agreeing on the above states, Local tour operators face planning challenges, as the number of excursion reservations may not be made known until a ship's arrival. This lack of foreknowledge can lead to supply and staffing inefficiencies, as well as shortages, crowding and overbooking of tours. This complexity involves passengers not receiving what they were expecting; it could be more or it could be much less. Dickinson and Vladimir (1996) identified further issues related to the shore excursions. According to their case study, the challenge is that the shore excursions, the very aspect of Seabourn's product that attracts many of its guests, are also, to a certain extent, beyond its direct control. Unlike a seven-day Caribbean cruise, where the ship visits the same port every week, a Seabourn ship may visit some ports only a few times a year. That means that they have to work harder (and usually pay more) to ensure the availability of best equipment and tour guides for their shore excursions, as the infrastructure in some areas is dominated by the larger tour operators who frequently patronize these service and facilities with charter tourists. Moreover, things often change; museums and other sites close for renovations, new ones open, and the recommended shopping and dining venues can change. Another issues related to shore excursion arises with the limited space. The competition for a space is highly noticeable in the small island destinations, where the ratio cruise tourists per resident are large. This is the case for Cozumel, a Mexican Island in the Southern Caribbean coast with a population of 73,000 . If they had to support, in a day, seven mega ships with twenty thousand passengers, the overcrowding would be imminent and extremely difficult to handle (Brida \& Zapata, 2009).Further to that, Dickinson and Vladimir (1996) stated, the success of shore excursions, however, has everything to do with the ports of call and the tours that local operators have been able to develop. This further emphasizes the need of provision of an exceptional service to the excursionists despite the challenges.

As cruise tourism has grown, demand for terminal facilities has also expanded. Port cities without terminals build facilities hoping to attract cruise ships. Klein (2011) cited 250 News (2010) that reports few real word cases in port development and expansions. According to their report about Prince Rupert and Campbell River, British Columbia, Campbell River's C $\$ 14$ million terminal has been used rarely; Prince Rupert's C $\$ 12$ million terminal has had less traffic than originally projected and expects little or no traffic in 2012. Klein (2005) originated the idea about the terminal expansions and building. According to her, many existing ports are either expanding what they have or building new facilities. Some are based on assurances from a cruise line. That was the case for Saint John, New Brunswick, which spent $\mathrm{C} \$ 12$ million on a cruise terminal, specially built to accommodate Voyager of the Seas. It subsequently learned in August 2004 that one-third of its cruise ship passengers would be lost in 2005 because the ship was replacing Saint John with Bermuda. The infrastructure limitations cause much pressure on other facilities as well. The swift arrival and departure of high volumes of cruise passengers, especially through turnaround ships, can put pressure on local tourism capacities, degrade the natural resources upon which they depend, and lower the overall level of tourist satisfaction. It is not surprising, therefore, that the cruise industry generates mixed sentiments in port communities (Thomas, 2015). The resource limitations have lead the ports to have a love-hate relationship with the cruise industry. They feel on the one hand that they are not getting a fair share of the cruise tourism revenues; but on the other hand, ports recognize the money they make from cruise tourism and are hesitant to speak up for fear that cruise ships will pass them by (Klein,2006). As a result, many ports are encouraging cargo ships than cruise ships. Ahola (2011) identified Chinese 
ports are used for cargo shipping and they do not offer passengers any shore experiences. This limits shore excursion opportunities for the cruise passengers.

The development of any sector needs strong policy frameworks that encourage, standardize and develop the industry. This is especially visible in developing countries those with no or less experience in cruise tourism. The World Travel and Tourism Council (WTTC) (2004) report states that regional authorities should undertake to develop and agree on a regional cruise ship tourism policy. Earlier Dunlop (2003), in his discussion of tourism negotiation issues for the ongoing General Agreement on the Trade in Services (GATS) recommended that the region should develop a regional policy towards cruise ship tourism with the objective to increase the collective bargaining power of destinations in the negotiations with cruise ships and maximize on-shore expenditures by cruise ship passengers, establish environmental standards for cruise operations, and mechanisms to increase the benefits of cruise activities to national economies. Hall (2011) also confirms the idea that the cruise industry lacks governance and official regulations.

Safety and security are key concerns of the tourists when selecting a destination, Tourism facilities in various parts of the world have been subjected to acts of terrorism, for example, Bali, Tunisia, Egypt, Kenya (WTTC, 2004). While there have been no recorded incidents of terrorism in the Caribbean affecting travel and tourism since the bombing of an Air Cubana flight in 1976, the Caribbean region is vulnerable particularly because the area is so dependent on tourism. The Achillo Laura, a cruise ship, was hijacked in the Mediterranean in 1985 and pirates, off the coast of Somalia, attempted to board the Sherbourn Spirit in November 2005 (UNEP, 2005).The media today is highly conscious of port security. When tourists are assaulted it not only reflects poorly on the cruise liner but on the port-of call. Cruise and port officials must assume that that ports-of-call are not only potential terrorism targets. Visitors to these ports-of-call may be assaulted or even kidnapped (Tarlow, Korstanje, Amorin, \& Gandara, 2012). Therefore, the excursion service providers have to be extra careful about the safety and security of the cruise tourists.

\subsection{Service Providers Related Challenges}

The challenges faced by shore excursion service providers are multi-faced. Tourism as a multisectorial industry, requires the contribution and support of other industries to sustain. As a result, the excursion service providers are getting the assistance of vehicle service providers, souvenir shops, restaurants, guides recreational activities and finally the attractions. Even cruise passengers' expenditures include those that are not part of the cruise itself, such as taxis, souvenirs, shore excursions, food and beverages, etc. Crew expenditures include restaurants, retail goods, recreational activities, transport, etc. (Brida \& Zapata, 2009). These service providers also face difficulties when working with excursion service providers. Klein (2011) stated CBC News (2010) regarding the difficulties faced by the taxi drivers in Charlottetown, Prince Edward Island. According to the CBC News, an authorized taxi picking up a cruise passenger at the port must give 30 percent of every fare to the cruise line (Klein, 2011). Those willing to pay the 30 percent 'fee' have access to passengers while they are still in the cruise terminal; other taxi drivers are left behind the security gate entrance to the terminal. Those barred from cruise passengers question the equitability of these arrangements. In addition to that, the service providers are further disturbed by informal service providers. According to Brida and Zapata (2009), cruise passengers create an artificially large demand only for some particular days. On other days, business is fought for by the informal salespeople (mobile) who also want to benefit from the presence of the cruise passengers. Another issue regarding sociocultural

authenticity is the knowledge and accuracy of information provided by on board port lectures and 
those leading the tours. Passengers tend to depend on these cruise ship employees for accurate information; however it frequently is limited or incorrect. According to a seasoned cruise lecturer, according to Klein (2011) there is a great deal of misinformation given by both cruise ship port lecturers and tour guides.

As mentioned in the previous paragraph, the restaurateurs also playing an important role in shore excursions. However, the high standards maintained by the cruise ships pressurize the restaurants to adapt to total new food safety and hygienic methods for a few days. In contrast, as identified by Lawrence (2004), the risk to passengers from food or cool noncarbonated beverages prepared and served by commercial local corers and consumes during shore excursions is an important source of illness not attributable to the ship's food or water handling. Several substantial shipboard outbreaks have been linked to gastrointestinal illness to which tourists have been exposed ashore. Consequently cruise ships have been advised to discourage passenger attendance at large, onshore catered meals that are not prepared and served by the ship's staff. Ritter and Schafer (1998) also identified that meals are usually provided on day excursions by an approved tourist-agency, as the ship operators are cautious not to expose their passengers to the incalculable risks of native restaurants. When complying with international standards, the restaurants have to bear an additional cost, which will be immediately transferred to the excursion service providers. Ultimately, whilst enjoying 20 to 40 percent income, the excursion service providers are further cornered in excursion operations.

Despite the growing importance of cruise ship tourism, few independent studies have been carried out in respect to shore excursions (Atherley, 2003). The previous literature provides valuable blueprints and knowledge on the challenges of cruise tourism in relation to shore excursions, but cannot be adapted easily and completely within the Sri Lankan context since different countries are surrounded by different contexts and environments, which in turn bring different challenges in shore excursions. Thus, as stated in the introduction chapter, Sri Lankan tourism literature is silent on challenges in cruise tourism in relation to shore excursions. Consequently, this paper aims to bridge this knowledge gap in this ever growing cruise tourism industry.

\section{Methods}

This study is of pilot and exploratory in nature as the known facts regarding the cruise tourism management and shore excursions are extremely limited. It is further expected to undertake a more comprehensive study based on the findings of this study. In the attempt to conduct this research, qualitative methods of participant observation and semi-structured interviews were conducted from March 2015 to November 2015, which is the peak cruising period to Sri Lanka. During this period 22 passenger ships arrived to Sri Lanka (Athukorala, 2015).

Fifteen (15) vessels were contacted through the Sri Lankan ground handling agents to interview the excursion managers and only eight (08) opportunities were given. Three (03) foreign ship excursion managers and five (05) foreign excursion assistants of the ships were interviewed. In addition to that, two (02) senior managers of the ground handling companies and six (06) operational executives of three (03) Sri Lankan companies were also interviewed during the data collection process. The duration of the interviews was $30-45$ minutes. The interviews took place in both Colombo port and Galle port. Also, in most cases, operations of the shore excursions did not allow strict planning of the interviews. Semi-structured interviews allowed the informants to speak spontaneously, while keeping some structure in the interview. Identities of the persons are omitted, and anonymity is secured. Only two ground handling agents allowed the researcher to collect data 
through participatory observation. As a result, the researcher assisted these two companies to organize and conduct two excursions to Pinnawala Elephant Orphanage and two Colombo City Tours. During these tours the researcher got the opportunity to interview transport service providers, guides, restaurateurs, managers of the shopping centres, and some foreign excursionists. Most cruise tourism studies today has been based on observational data due to the distinct nature of the industry (Brida \& Zapara, 2009). Industry reports, book chapters, journal articles and reports of Sri Lanka Tourism Development Authority and World Tourism Organization were used as secondary data.

The resultant data was consolidated and analysed. Further, a descriptive approach was used to analyze the data with unattributed quotes to preserve anonymity, yet also to illustrate dominant issues in respondents' own words. This allowed the researcher to identify emergent recurring themes, contributing to the evolution of a more comprehensive understanding of the challenges faced by the Sri Lankan ground handling agents. The validity and reliability of the study was ensured by referring closely to previous work undertaken relevant to the cruise operation and challenges in international context. Further, when the findings of interviews and participatory observation conflicted, the researcher re-discussed, verified and validated the findings with local interviewees. The findings are presented and discussed in the next section.

\section{Findings}

The challenges faced by the shore excursion service providers are presented in three aspects: Firstly, economic, natural and socio-cultural challenges in shore excursions. Secondly, demand, supply and infrastructure related challenges, and finally, service providers related challenges.

\subsection{Economic, Natural and Socio-Cultural Challenges in Shore Excursions}

A destination earns through cruise tourism in many ways: shore excursion income, port facility charges, tourists' expenditures, car rental services etc. Out of all, shore excursion income happens to be the greatest source of income. However, the shore excursions are sold to the cruise tourists by the ship itself with a significant margin. As explained by two ground handling managers and an executive:

Different ships keeps different margins from shore excursions. Usually, what the tourists are paying to the ship is 30 percent to 200 percent higher than what we are receiving. This is one of the main sources of income to the ships as well.

The ships call for one day excursion quotations from us few months before the call, and they start selling it along with the package to the clients, at a higher rate, 2 - 3 times. It make them to earn money when the ship is not even in the sea.

The ships charge some big money from the cruise tourists and we are getting just an average profit. The clients do not know this and some clients are demanding superior services and facilities during an excursion, which we are unable to provide.

Another significant negative impact lies in the traffic congestion that is created by the large number of tourist carrying vehicle convoys especially buses (coaches) and cars that add to the already congested city traffic. While during the peak rush hours of school traffic, office times and during the school holidays and long weekends the situation gets aggravated. The researcher further observed the vehicle parking related issues in many key tourist attractions, especially in Kandy Temple of Tooth Relic, Colombo Zoo, Gangarama Temple and Pinnawala Elephant Orphanage and Peradeniya 
Botanical Garden that create much problematic situations to the tourists. A huge traffic jam is created when the tourists are getting off of the buses and getting back to the buses.

Also, over-crowding of destinations and poor visitor management techniques at destinations leads the destinations to appear as they are unattended. The observations further explored that places like Temple of Tooth Relic, Gangarama Temple, Kelaniya Temple and Pinnawala Elephant Orphanage are overcrowded when the cruise groups are visited. A devotee at the Temple of Tooth Relic expressed her opinion about the tourists as follows:

We came from Matara early in the morning and we wanted to see the sacred Tooth Relic of Lord Buddha and pay our homage here. I was in the queue for about 20 minutes because there are so many tourists. After that I sat on the floor to worship, but could not do it properly as the tourists are always coming, going and it disturbs me.

When inquired from the officers at the main attractions it was revealed that visitor management techniques are not being practiced at the sites. This will be a serious issue in the future. Further to that, it was observed that the absence of toilet facilities for the guests at the Ma Oya (Ma River) in which the elephants are taken to bathe. According to a manager of a leading restaurant in the river bank:

The Elephant Orphanage has failed to provide adequate toilet facilities for the guests. For instance, there is no proper toilet maintained by the Orphanage outside the premises. Some guests never the Orphanage, but they pay US \$22 and just enjoy the River Bathing of the Elephants. When big groups like cruises come, no matter they have a reservation at the restaurant, we have to provide toilet facilities. But we cannot do this forever.

The literature is very concerned about the environmental impacts to successful shore excursions. However, Sri Lankan weather has always been favourable to the cruise operations. But, there has been one occasion in year 2012 where one ship could not berth in Galle harbour due to the rough sea. As explained by one tour executive:

In 2012, Winter Season, we were fully ready for the Galle operation with one of our regular ships. Unfortunately, it rained all night long and the following day morning the wind was very heavy which turned the sea in to very rough. The ship decided not to anchor in Galle harbour.

Whilst this type of situations does not cost the operator immensely due to the insurance coverage they have, the other service providers including guides, restaurants, buses had been disappointed since they lost the commission.

Although the quality of life in small islands are greatly affected with the arrival of cruise ships (Brida \& Zapata, 2009), neither interviews, nor observations could find facts on similar situations in Sri Lanka except inside the attractions, which are concerns of the pilgrims at the Temple of Tooth Relic.

\subsection{Demand and Supply Related Challenges}

To comply with the demands of this international niche segment, not only the excursion operators, but also the Port Authority has to keep high level of standards in every service they are rendering. According to a senior manager, it was disclosed that the excursion service providers are facing some challenges due to accessibility issues. The manger stated his comments as follows:

The accessibility is restricted through the Gate 1, and Chaitiya Road, which is the ideal access to the

Passenger Jetty. Also, the road congestion in A1, A2, A4 roads and other roads. 
According to Port Marlborough report on 'Cruise Industry Background' (2012), usually, a cruise line will consider a new port only if the onshore capacity is able to accommodate at least half of the ship's capacity. According to Dole, the president of Cruise Tourism Sub-committee of SALITO:

There are no holding areas for joining in and leaving passengers in or near the port of Colombo due to lack of a cruise terminal. It is the high time for us to look for alternatives. The unavailability of holding areas can be overcome for instance by converting the Grand Oriental Hotel or part of the Old main Ports Authority Building next to the Grand Orient Hotel into a cruise terminal hall, with minimal investment.

Further studies revealed some more evidences related to the challenges that operators are facing at the harbor. Colombo being a major cargo hub, has the necessary port facilities to support the berthing of very large ships, including the largest cruise ships presently plying around the world. During the interview with a manager of a Sri Lankan agency, the importance of port expansion project was emphasized while explaining some difficulties they are facing at the port as follows:

There is only one dedicated passenger berth of 200 meters length. This berth is inadequate for the larger cruise ships to dock. While the Port of Colombo has the longer and deeper berths to cater to container cargo ships, cruise lines have to compete with the big container operators for berthing space, since the regular cargo carriers provide much better revenue to the Port than the Cruise Lines. This is because apart from the berth rental, they also generate a lot of container handling.

However, in contrast to that, another manager of a leading Destination Management Company (DMC) stated

Sri Lanka does not receive a large number of cruise ships as at now. Therefore there is no ship traffic or a competition between cruises and cargo ships. But, in the year to come, there will be.

A cruise line sees a direct relationship between passenger satisfactions and going on a tour, hence they want to know a port has enough onshore capacity, to entertain their passengers and give them a satisfactory visit. The limited number of suppliers in the country restricts the supply segment in Sri Lanka. During the interviews it was also disclosed that there is a limited number of cruise management companies in Sri Lanka. Three operational executives shared the same constraint as follows:

Responding to a cruise call is not easy. For which we need much planning. Except a few large companies in Sri Lanka, other companies do not have the capacity to handle a ship alone.

When we are bringing a ship down to Sri Lanka, we have to join with many other operators in the region. These regional operators are facing a huge competition with other regions to secure a cruise ship to Sri Lanka. However, when there are a few supplier in Sri Lanka, they doubt about the destination's capacity to handle back to back ships.

Cruise handling is a different job. It required distinct knowledge and skills. As a result not all Destination Management Companies in Sri Lanka are trying at bringing ships to Sri Lanka. So the total number of ships we receive are limited.

The core issue related to above issues need a holistic investigation. When reviewing the international literature it was disclosed that presence of conducive policies always make a destination stronger with proper planning and development. However, the secondary data left no trace of availability of such policies to promote the cruise tourism in Sri Lanka. The ports and airport come under the purview of the Ministry of Ports and Aviation in Sri Lanka. While other line ministries such 
as, the Ministry of Finance (Customs) and Ministry of Tourism and Christian Religion Affaires as well as the Ministry of Defence (Border Control) are jointly responsible for policy related to Cruise Ship Tourism. At present there is no specific policy pertaining to promotion of Cruise Ship Tourism in Sri Lanka. According to Dole:

Even in the 2016 Tourism master plan, the cruise segment was not included enthusiasm and drive is very positive given that there is a 9 percent cater growth in the last nine years globally even when the whole recession which is the purchasing power of cruise travellers.

The cruise calls are extremely sensitive to the level of security. Dole noted that the advantage for the Port of Colombo is that it has got a good record in complying with the International Ship \& Ports Security (ISPS). With the various security controls that is mandated by International Containerized Cargo Carriers, which Sri Lankan Ports have complied, in its quest to become a maritime and logistical hub, facilitates the calling of Cruise Lines. Further to that, according to a foreign tour excursion manager:

One of our prime concerns at a port is the security. The companies have invested billions in a ship and it is our main responsibility to protect it and its passengers. Although Colombo harbour comply with ISPS requirements, we keep a safe margin between the vessel and locals, especially the vehicles.

Another difficulty that the shore excursion operators face is protecting the clients from beggars, street children, three wheel drivers and peddlers. The tourists are much keen about the locality they are visiting. If they are disturbed or harassed at a destination by any means, the tourists will stop touring at that destination and ultimately the liner has to stop the call. Two foreign excursion managers also commented about the undesirable conditions of locals in the vicinity

In most cases, the clients inquire about the people living in and around the port of call. We all know cruise passengers are up class people who do not prefer to be disturbed by the touts and beggars. If we comment frankly about the Colombo and Pinnawala touts, we would not get the clients.

The cruise passengers are frequently disturbed by the local vendors and tuktuk drivers. So we are advising our local agents to keep the clients always away from the disturbing locals.

The researcher also observed that the excursionists are disturbed in the Pettah Bazaar and Pinnawala Elephant Orphanage by offering different services including three wheel rides, elephant back safari rides, free massages at spice gardens, exchange of money and by trying to sell the souvenirs.

Extensive investigation in to literature led the researcher to come across with a promotional material that promotes excursions which came with the disclaimer, "Shore excursions are not operated by the Carrier. The Carrier is not responsible for the performance of shore excursions or for any losses, injuries, or damages occurring ashore whether during an organized excursion or otherwise" (Celebrity Cruises, 1995). Although it is not clear whether this practice is still being practiced, the operators collectively have to keep the standards higher as much as possible.

The demand related challenges are extensive to discover. Another issue identified in this study is excursionist related. Traditionally, a tour operator knows even weeks before how many clients he can expect on a given date. However, it is contrasting in cruise tourism as the passengers tend to make last minutes bookings. According to some executives:

We would love to have as much as clients to take in our tour. However, when the number of clients are increasing at the very last minute we are pressurized as our supplies are limited. 
The ship starts promoting the shore excursions six months before as well as the day the excursion takes place. So we always have to keep extra supplies: vehicles, guides, lunch reservations to meet that order.

\subsection{Service Providers Related Challenges}

The excursion service providers are meeting various types of difficulties during the shore excursions. Another aspect of these challenges is suppliers related. Shortage of suppliers and reliability of the suppliers are key challenges to overcome during shore excursions. The elite nature of the clients makes this challenge stronger. According to the operational executives:

Cruise tourism involves mass handling of high class tourists. Thus we must maintain the standards as high as possible. However, reserving more than 20 luxury coaches in equal standards are extremely difficult during the peak periods. Also, we need to hire the service of good national guides to each of these buses, which is tough.

We always find it difficult to secure a large number of buses when large passenger ships are calling. Thus, we make reservations months before anchoring.

Finding good buses is a challenge, finding good guides is a challenge, securing good restaurants is a challenge. The best strategy is to reserve everything months ahead.

During both interviews and participatory observation it was noted that the Sri Lankan agents are taking an extra care to keep the services of the suppliers at a standard level. The level of services rendered by these suppliers is at a debate. According to the Sri Lankan operational executives:

In cruise operations the operators always have to outsource certain services including vehicles, resting areas, transit areas, guides, restaurant and operational staff.

Sri Lankans, as you know, are not punctual and we have many bad experiences about them. Therefore, the reliability of the service providers are at an average level and there had been some occasions that vehicles do not show up on time and other suppliers do not cope up with the standards.

Our suppliers are not reliable. Therefore we always double check their services even the day before. For example, we always ask the buses, coaches to come on the previous day. Also, at every destination and every restaurant we employ one of our employees to keep an eye on everything.

Guides have the first hand encounters with tourists. If the guides commit a mistake or exhibit any unethical behavior, the tourists tend to judge the country based on that stand point. With the present tourism boom, the demand for National Tourist Guides have gone up and as a result the cruise operators finding it difficult to reserve $30-50$ number of guides with good standards to serve to a ship's call. It was observed that different guides are having different competencies and there were occasions that the excursionists are complaining about the service of the guides. According to one tourist who visited Pinnawala:

Me and my husband took the bus number 03 and two of my friends were in some other buses. During the lunch we heard that how competent their guide to explain about Sri Lanka, the nature, culture and heritage. They had been told many stories where as our guide just turned to be a conventional guide with average knowledge in English.

The researcher also observed that different styles of delivery of guides, which are unavoidable. But as long as the guests are concerned about these differences the guides have to provide a standard 
service. The importance of qualified tourist guide lecturers for excursions was identified by Dowling (2006) as well.

Other than the transport and guides, the attention was paid upon the quality of the restaurant services as food poisoning is one of the worst nightmares of the tourists as it can jeopardize the overall guest satisfaction. To avoid that risk, the ships are recommending to the restaurants and hotels to follow special standards in food processing. In order to meet this requirement, it was observed that the operators are given a check list from the ship. It was further observed that, officers of the agents are making random visits to the industrial kitchen on the day before and even during the time, when the food is being processed, to make sure that the hotels and restaurants follow those standards. The researcher also got the opportunity of walking to the kitchen of the restaurants and to measure the level of hygiene before the clients sit for the meals. The study supported a 1996 report in the Journal of the American Medical Association which estimated that one-third of gastrointestinal outbreaks on cruise ships might be prevented if onshore caterers were not used for off-ship excursions. Therefore it is important to maintain the standards higher.

\section{Discussion and Implications for Shore Excursions}

Implications of the study are presented in three distinct aspects: findings that comply with the previous literature, findings that contradicts to the literature and the distinct challenges faced by Sri Lankan shore excursion service providers.

The study revealed that the cruises sailing to Sri Lanka are earning a handsome profit through selling shore excursions. Thus, the study agrees with Klein (2002), Klein (2005), Dowling (2006), and Brida and Zapata (2009) on their arguments that cruises are keeping a significant margin for themselves when selling shore excursion packages. Further, the study agrees with UNEP (2005), Klein (2005) and Klein (2011) about the traffic congestion caused by excessive number of vehicles that transfer the tourists to main tourist destinations. The observant data explored that the traffic is caused in Pinnawela, Kandy, and in Colombo Outer-port roads in Sri Lanka. In the meantime, the study supports the previous studies carried out by Klein (2005), Klein (2006), Ahola (2011) and Thomas (2015) on the fact that limited port facilities discourage cruise tourism development in a country. It was further discovered that the safety and security of Colombo harbor is complying with the standards of ISPS. This requirement is highlighted in the studies conducted by WTTC (2004), UNEP (2005), and Tarlow et al., (2012). In addition to that, Sri Lankan restaurants at the main tourist attractions were found to be at a favourable condition as per the ship requirements. Availability of food at a safe and a hygienic condition is a must factor in cruise tourism according to Ritter and Schafer (1998), Lawrence (2004), Brida and Zapata (2009).

However, the study identified that Sri Lanka as an island do not face difficulties because of cruise tourism in terms of change in life style, townships being over crowded, unavailability of public transport as explored by Dowling (2006), and Brida and Zapata (2009). One of the reasons for that is, Sri Lanka having multiple attractions in the country and therefore tourist groups are not flocked in to one particular place. In addition, although public transportation services are used in certain European and Caribbean Islands, for the travel purposes of the cruise tourists, Sri Lankan operators maintain a separate fleet of vehicles to meet the tourists' transportation needs. Further, it was discovered that the cruise ships calling in Sri Lanka do not enter into a competition with cargo ships as seeing in other main cruise destinations in Europe and Caribbean Islands. Thus the study is contrasting to the findings of Aloha (2011). Another contrasting finding to UNEP (2005) is that, Sri Lanka is positioned in an 
ideal location for cruising as Sri Lanka is not affected with bad weather conditions like hurricanes or tornadoes. There is no record of a cruise ship cancelling its call to Sri Lanka due to traumatic weather conditions.

The study made interesting discoveries on the challenges in tourism in relation to shore excursions in Sri Lanka. First, in relation to the income, it was discovered that ships start earning through selling shore excursions even before they start sailing. In order to maximize the revenue, the Sri Lankan tour operators can get together and develop a cruise excursion tour package system online. With appropriate marketing techniques, this will be successful over time. In Europe and other developed cruise destinations, this type of systems are available. It was further discovered that Sri Lankan main tourist destinations are not sufficient to accommodate a large number of luxury coaches, especially in Pinnawela, Kandy, Gangarama, Colombo Zoo and even in Peradeniya botanical garden. Thus, it is proposed to expand the existing parking facilities at destinations. The operations of Sri Lankan excursion operators are also challenged due to non-availability of visitor management techniques. As at now, there is no resistance from the public at religious and other attractions, but the increased number of cruise tourists in near future will change the situation. Thus, the authorities need to pay careful attention on visitor management techniques.

In Sri Lanka, the tourist - focused facilities at the attractions are poorly planned and developed. For example, there is no toilet for the cruise tourists in the Ma Oya river bank. Also, there is no proper shed for the tourists to get the protection from the rain and the sun. The dissatisfied clients will eventually spread the negative word about Sri Lanka and ultimately the number of tourists visiting the destination will be decreased if sufficient measures are not taken. Further to that, to generate more revenue to Sri Lankan ground handling agents, the Port Authority has to introduce a passenger terminal as suggested by an industry expert; the recommendation is to have a holding area at the Ports Main Building or Grand Orient Hotel for passengers to embark and disembark when they have to join or leave the ship. So that new passengers can join, or on board passengers can depart, leaving the country from the port of call. The most successful ports have dedicated cruise terminals, with minimal inconvenience and only essential barriers, which are well manned and organized to eliminate delay and waiting.

In addition to that, in order to solve the policy related issues, Sri Lankan Government should develop a comprehensive cruise tourism policy that covers the following areas as per industry demands: simplified and efficient immigration and border facilitation; rapidly clearing the ship of customs formalities; passengers, animal and plant quarantine; clearing of the ship for passenger disembarking through efficient custom procedures; port and naval security; berthing facilities with tug and pilotage; regulate the tourism service providers to prevent touting and unscrupulous activities; educate local communities and micro enterprises on the benefits of tourism; ensure that local service providers of food and drink around the touristic sights meet basic hygiene standards; ensure that all the touristic sights have proper toilet and washroom facilities that are properly maintained; provide promotional support of the destination, starting with Colombo and extending to Galle, Trincomalee and other ports. Most importantly the government should take vigorous actions on developing national policies on cruise tourism development and promotion. Cruise tourism should be identified as a growing tourism segment with the potential of generating foreign currency. Thus, serious measures should be taken to protect and develop the cruise tourism industry. Also, the reasons that make the cruise passengers uncomfortable and harassed should not be tolerated. As such, beggars and street children need to be removed from all tourist sites. The services of three wheel drivers and peddlers 
need to be standardized through awareness programs, training and development. Further to that, both SLAITO and the National Tourism Authority should develop a common database of guides, vehicles, restaurants and other service providers and they should be trained with the assistance of industry experts. Additionally, the authorities need to pay attention on the areas where there are vacuums, and remedial actions need to be taken especially with respect to limited number of vehicles and guides.

Future extensive studies need to be carried out to identify the public opinion about the mass tourist movements in Sri Lanka including roads and main tourist destinations. In addition to that, environmental impacts of shore excursions need to be explored as the literature is silent on it. Also, the study suggests measuring the carrying capacity at each destination to develop visitor management techniques.

\section{Conclusion}

Cruise tourism is a growing niche market in the world. Out of all other cruising destinations, Asia in particular has got the attention of international cruise operators searching for new destinations to please its high end clients. The shore excursion operators are rendering their services to the principles irrespective of many structural, policy related and bureaucratic bottlenecks just because they are passionate about the industry. The identified challenges are either similar or contrasting to the previous literature and unique challenges in shore excursions in Sri Lankan context were also identified and implications are drawn. The paper is merely a preliminary study about shore excursions in Sri Lanka. It is aimed to use this study as an initial material for future researches. There is much to do including collecting data from cruise ships sailing to Sri Lanka, cruise tourists, shore excursion service providers, and thereby provide results that can be used by the Governments and industry professionals to heighten the net benefits of cruise tourism that can be kept within Sri Lankan shores.

\section{References}

Ahola, A. (2011). Creating a consumer-driven business model for the cruise line industry: Case Royal Caribbean Cruise Lines Limited. Tiivistelma: Aalto University.

Ajagunna, I., \& Pinnock, F. (2013). Challenges for the cruise industry and port-city governance: The case of the Caribbean. Kingston: Retours D'expériences Internationals

Atherley, K. A. (2003). Cruise industry-related challenges facing the Caribbean destinations. Washington, DC: Inter-American Committee on Ports.

Athukorala, R. (2015, October 22). Tourism news. Retrieved from Visit Sri Lanka: www.srilanka.travel.

Berkmoes, V. R., Butler, S., \& Stewart, I. (2014). Lonely Planet Sri Lanka. Chicago, IL: Lonely Planet.

Brida, J. G., Del Chiappa, G., Meleddu, M., \& Pulina, M. (2012). Cruise tourism externalities and residents' support: A mixed approach. Economics, 6(40), 1-26.

Brida, J. G., \& Zapata, S. (2009). Cruise tourism: Economic, socio-cultural and environmental impacts. International Journal of Leisure and Tourism Marketing, 1(3), 205-226.

Celebrity Cruises. (1995). Tips for a great excursion. Miami, FL: Celebrity Cruises Limited.

Dickinson, R. H., \& Vladimir, A. N. (1996). Selling the sea: An inside look at the cruise industry. New Jersey: John Wiley and Sons.

Dowling, R. K. (2006). Cruise ship tourism. Joondalup WA: Edith Cowan University. 
Dunlop, A. (2003). Tourism services negotiation issues: Implications for CARIFORUM countries. Barbados: CRNM.

Dwyer, L., \& Forsyth, P. (1996). Economic impacts of cruise tourism in Australia. Journal of Tourism Studies, 7, 36-45.

Godahewa, N. (2012). Refreshingly Sri Lanka. Colombo: Ceylon Sights (Pvt.) Ltd.

Hall, C. M. (2011). Policy learning and policy failure in sustainable tourism governance: From firstand second-order to third order change. Journal of Sustainable Tourism, 19, 649-671.

International Luxury Travel Market (2011). The future of luxury travel. New York, NY: Horwarth HTL.

Johnson, D. (2002). Environmentally sustainable cruise tourism: A reality check. Journal of Marine Policy, 26(1), 261-270.

Klein, R. A. (2002). Cruise ship blues: The underside of the cruise industry. Gagriola Island, BC: New Society Publishers.

Klein, R. A. (2005). Cruise ship squeeze: The new pirates of the seven seas. Canada: New Society Publisher.

Klein, R. A. (2006). Turning water into money: The economics of the cruise industry. In R. Dowling (Eds.), Cruise ship tourism (pp. 261-269). Wallingford: CABI International .

Klein, R. A. (2011). Responsible cruise tourism: Issues of cruise tourism and sustainability. Journal of Hospitality and Tourism Management, 18(1), 107-116.

Lawrence, D. N. (2004). Outbreaks of gastrointestinal diseases on cruise ships: Lessons from three decades of progress. Current Infectious Disease Reports, 6(2), 115-123.

Loper, C. (2005) New Orleans, Lousiana. Impacts of cruise tourism. Proceedings of the 14th Biennial Coastal Zone Conference (pp. 17-21). Lousiana: University of Delaware.

Luković, T. (2012). Nautical tourism and its function in the economic development of Europe: Visions for global tourism industry- Creating and sustaining competitive strategies. Retrieved from cdn.intechopen.com

McKenzie Wilson Network Partnership Group. (2004). The potential of cruise tourism in North East of England: A market assessment, economic impact and image assessment. Cruise Tourism. Retrieved from One North East: http://www.onenortheast.co.uk/lib/liDownload/460/ final_report.pdf.

Ministry of Economic Development. (2011). Tourism development strategy 2011-2016. Colombo: Author.

Pallis, T. (2015). Cruise shipping and urban development: State of the art of the industry and cruise ports. Chios: University of the Aegean.

Port Marlborough (2012). Cruise industry background. Marlborough: Port Marlborough New Zealand Limited.

Power, J. D. (2013). Cruise line satisfaction report. Retrieved from http://www.jdpower.com

Ray, R., \& Williams, P. (2003).Potential spatial and management implications of cruise ship passenger activity on the development of the North Coast. Alaska: Simon Fraser University.

Ritter, W. \& Schafer, C. (1998) Cruise-tourism. Tourism Recreation Research, 23(1), 65-71.

Sri Lanka Tourism Development Authority (2015). Annual statistical report- 2014. Colombo: Author.

Tarlow, P., Korstanje, M. E., Amorin, E., \& Gandara, J. M. G. (2012). Cruise risks, threats and dangers: A theory. American Journal of Tourism Research, 1(1), 16-25.

Tercek, J. (2015, September 25). Global cruise tourism trends and initiatives for Sri Lanka in order to develop the cruise tourism segment. In B. Dole (Moderator, Panel Discussion), Colombo International Maritime Conference. Colombo, Sri Lanka 
Thomas, J. M. (2015). Economic opportunities and risks of cruise tourism in Cairns. Cairns: James Cook University.

Tourism Queensland (2006). Cruise destinations. Queensland: Thompson Clarke Shipping.

United National Environment Programme. (2005). Issues and challenges in Caribbean cruise ship tourism. London: Author.

United Nation World Tourism Organization. (2011). Cruise tourism. Madrid: Author.

World Travel and Tourism Council (2004). The impact of travel \& tourism on jobs and the economy. London: Author. 